\title{
Morphology of the Pericarp and Seed of Tabebuia chrysotricha (Mart. ex DC.) Standl. (Bignoniaceae)
}

\author{
Luiz Antonio de Souza; Maisa C. Iwazaki and Ismar S. Moscheta \\ Departamento de Biologia; Universidade Estadual de Maringá; Av. Colombo, 5790; 87020-900; lasouza@uem.br; \\ Maringá - PR - Brazil
}

\begin{abstract}
The morphology and anatomy of the fruit and seed of Tabebuia chrysotricha (Mart. ex DC.) Standl. (Bignoniaceae), a species typical of the Atlantic rainforest, is presented and discussed. The fruit was a loculicidal capsule, dehiscing through two slits, liberating a seminiferous column. The dehiscence process of the fruit involved separation tissue and two crossed sclerenchymatous mesocarpic layers (middle and subepidermic). The seed originated from an anatropous, unitegmic and tenuinucellate ovule. It was exotestal and presented polyembriony. The endothelium and endosperm were conserved in the mature seed and protected the embryo. Adventive embryos were made up of hypostase cells.
\end{abstract}

Key words: Tabebuia chrysotricha, Bignoniaceae, fruit, seed, anatomy, morphology

\section{INTRODUCTION}

Tabebuia chrysotricha (Mart. ex DC.) Standl. ("ipê-amarelo") is a species belonging to Bignoniaceae that is very often used as an ornamental plant in parks and gardens, as well as in the lining of streets. It is a deciduous plant and a heliophyte typical of the Atlantic rainforest. Its wood is suitable for external works such as posts, bridge pieces and fence boards; it is also used in civil construction (Lorenzi, 1992).

Structural studies of fruits and seeds of species native to Brazilian forests, especially Paraná State, are fundamental to the process of forest preservation and recovery. However, Brazilian works on this subject are very scarce, mainly those that refer to forest species belonging to Bignoniaceae. Among those that can be cited are on the seed of Tabebuia serratifolia (Vahl) Nicholson (Costa, 1995) and on the pericarp and seed of Tabebuia ochracea (Chamisso) Standley (Costa, 2003). Investigations of Bignoniaceae fruits also have taxonomic value, being important for the definition of tribes and genera of this family (Barroso et al., 1999). In addition, in Tabebuia Gomes ex DC., the "ipê" fruits are structurally difficult to define. This study analyzed the morphology of the developing pericarp and seed of $T$. chrysotricha, as well as the correct determination of its fruit.

\section{MATERIALS AND METHODS}

Botanical material (floral buds, flowers and fruits in different developmental stages) of Tabebuia chrysotricha specimens were collected on the campus of Universidade Estadual de Maringá (Paraná State, Brazil) and fixed in FAA (Johansen, 1940). Semi-permanent slides with cross- and longitudinal sections (done freehand) stained using safranin and astra blue were made. Sections of botanical material embedded in paraffin wax were also obtained using microtome techniques 
(Johansen, 1940) and were stained using Ehrlich hematoxylin and safranin (Johansen, 1940), in accordance with the simplified method of Dnyansagar (1958). Microchemical tests were carried out for lipids (Sudan IV), starch (IKI) and lignin (phloroglucinol and sulfuric acid) (Johansen, 1940; Berlyn and Miksche, 1976).

Morphological description of the developing fruits and seeds was based on Corner (1976), Roth
(1977) and Barroso et al. (1999). Drawings were made using an optical microscope and a stereomicroscope, equipped with a lucid camera. The respective micrometric scales were prepared in the same optical conditions as the drawings. Vouchers were deposited in the Herbarium of Universidade Estadual de Maringá (Paraná State, Brazil), Campus of Universidade Estadual de Maringá (fl), M. C. Iwazaki 10156 HUM.
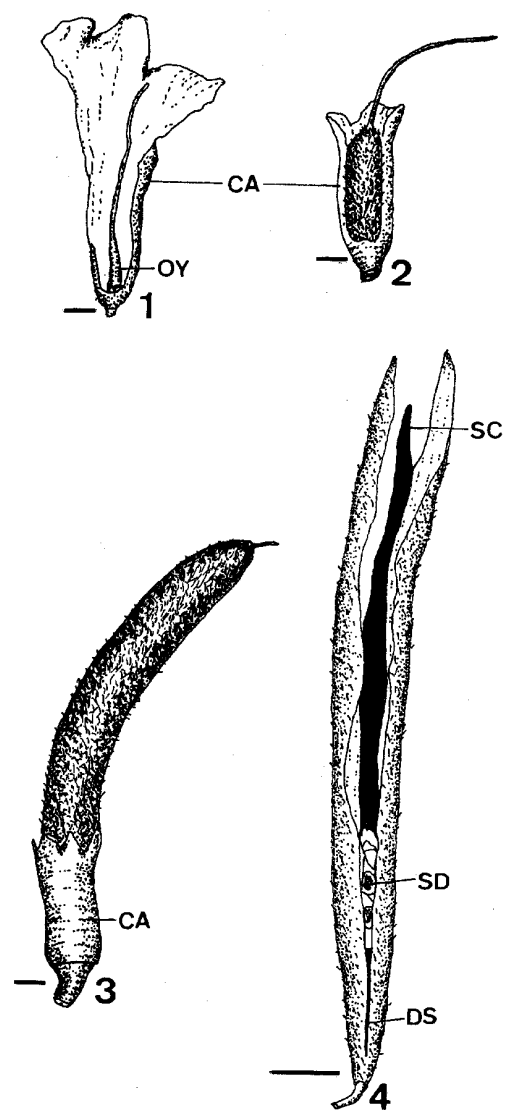

Figures 1-4 - 1 - Flower with ovary (Bar=5 mm); 2-3: Young fruits $($ Bar=5mm); 4: Mature fruit $(\mathrm{Bar}=2 \mathrm{~cm})$. (CA-calyx; DS-dorsal suture; OY- ovary; SC- seminiferous column; SD-seed)

\section{RESULTS}

\section{Pericarp}

The ovary was superior (Fig. 1), having two carpels and two locules, as well as axial placentation (Fig. 5). The ovary presented a uniseriate outer epidermis with a cuticle and a large number of developing trichomes (Fig. 7).

The ovary mesophyll (Fig. 7) was parenchymatous with polyhedral and thin-walled cells. The parenchymatous subepidermic cells of the mesophyll showed evidence of periclinal divisions. In the middle mesophyll, there were collateral vascular bundles. The inner epidermis was also uniseriate, glabrous and had tabulate cells (Fig. 7). In the dorsal suture of each carpel, the precursor separation tissue of the mature fruit was delineated (Fig. 5). The septum (Fig. 5) was formed by placentas that were fused and had an epidermis, a parenchyma, marginal vascular bundles and ovular traces. 
The young fruit was pilose, being involved by the calyx (Figs. 2 and 3). The differentiation of the ovary wall in the pericarp was marked initially by the abundant formation of multicellular thinwalled tector trichomes (Fig. 8) and few glandular trichomes in the young exocarp. The mesocarp underwent intense meristematic activity in the middle region, where vascular bundles occurred (Figs. 6 and 8). Two or three layers of subepidermic mesocarpic cells began tangential lengthening and the cell walls became a little thicker (Fig. 8). The inner epidermis came to have more elongated and thick-walled cells (Fig. 8).
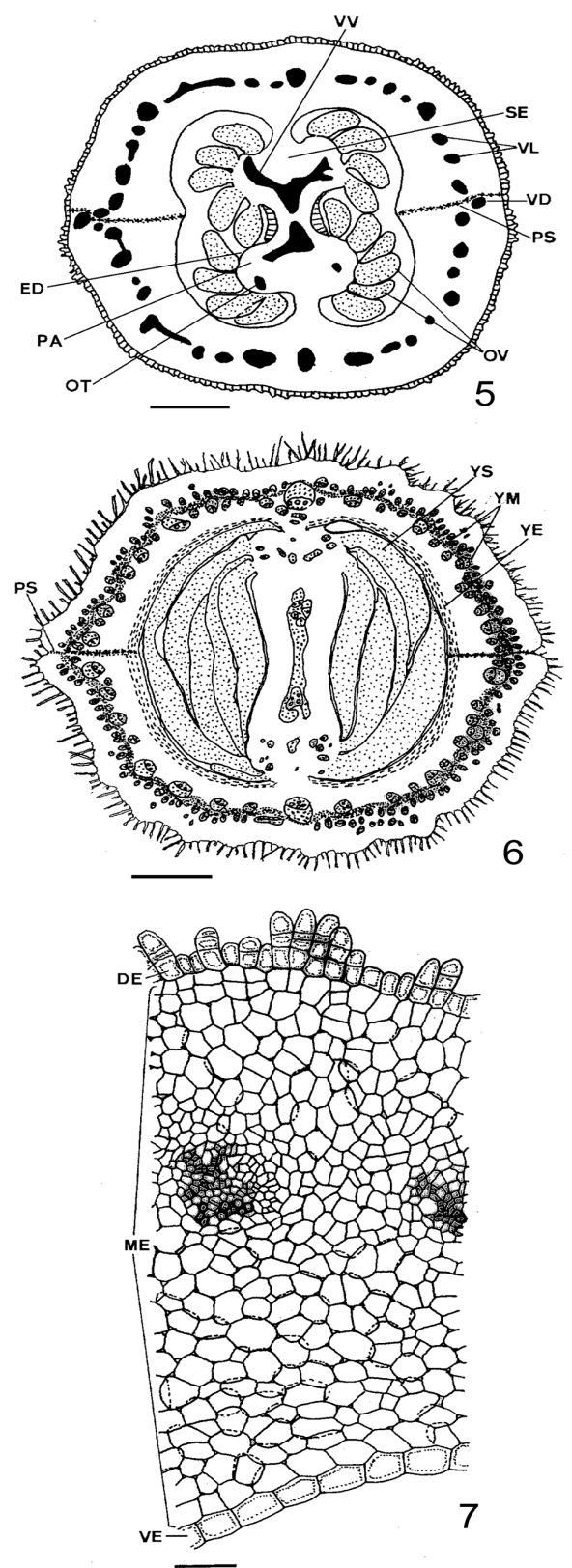

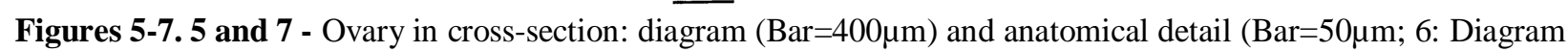
of young fruit in cross-section (Bar=1mm). (DE-dorsal epidermis; ED-epidermis; MEmesophyll; OT-ovular traces; OV-ovules; PA-parenchyma; PS-precursory separation tissue; SE-septum; VD-dorsal vascular bundle; VE-ventral epidermis; VL-lateral vascular bundles; VV-ventral vascular bundle; YE-young subepidermic mesocarp and sclerenchymatous endocarp; YM-young middle sclerenchymatous mesocarp; YS-young seed) 

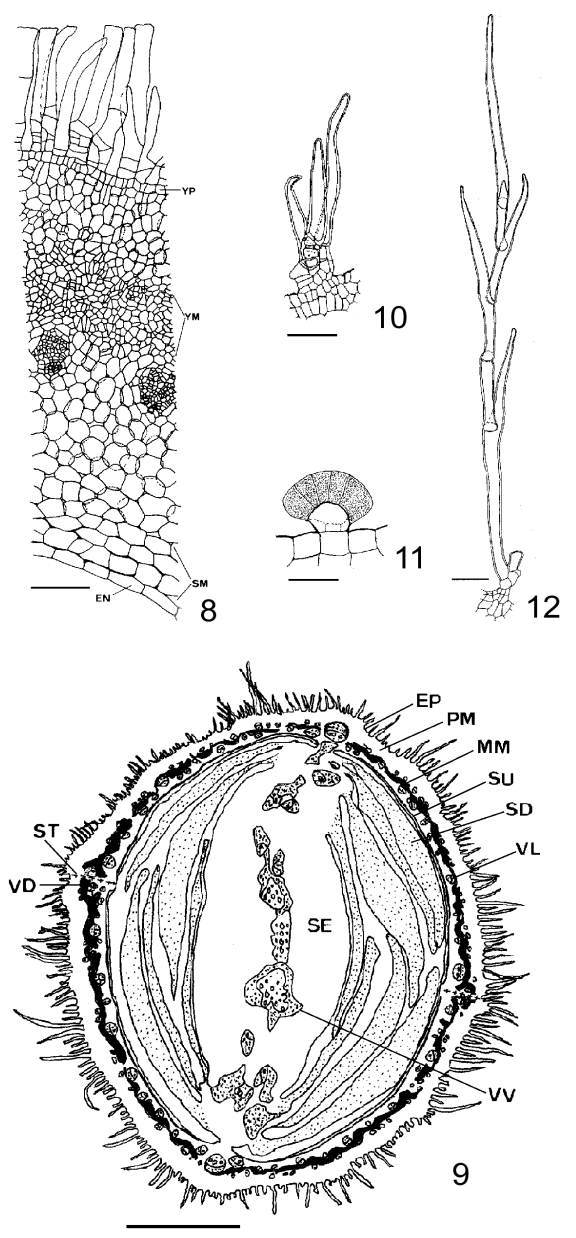

Figures 8-12. 8 - Anatomical detail of young fruit in cross-section, shown in Figure 6 (Bar=100 $\mu$ m); 9: Diagram of mature fruit in cross-section, still non-dehiscent $(B a r=0.5 \mathrm{~cm}) ; 10-12$ : Epicarp trichomes; 10: Short ramified tector trichome $(\mathrm{Bar}=100 \mu \mathrm{m}) ; 11$ : Multicellular glandular trichome $(\mathrm{Bar}=20 \mu \mathrm{m})$; 12: Long ramified tector trichome $(\mathrm{Bar}=100 \mu \mathrm{m})$. (EN-endocarp; EP-epicarp; MM-middle sclerenchymatous mesocarp; PM-parenchymatous mesocarp; SD-seeds; SE-septum; SM-young subepidermic sclerenchymatous mesocarp; ST-separation tissue; SU-subepidermic sclerenchymatous mesocarp; VD-dorsal vascular bundle; VL-lateral vascular bundles; VV-ventral vascular bundle; YM-young middle sclerenchymatous mesocarp; YP-young epicarp)

Differentiated tector and glandular trichomes were observed in the exocarp of the immature fruit. They can remain until the adult stage. Tector trichomes (Figs. 10 and 12) were simple or branched and multicellular, with short basil and pitted thick-walled cells. The apical cells of the tector trichomes were thin at the end (Figs. 10 and 12). The glandular trichomes presented a short pedicel and a multicellular secretory apex (Fig. 11). In the young fruit, cellular lengthening of the mesocarp occurred, i.e. fiber primordia located among vascular bundles and inner subepidermic cells. The inner epidermis of the pericarp also showed tapered-end cells.

During fruit development, it was observed that the septum, located among the placentas, underwent tangential growth, pushing the young seeds toward the pericarp (Fig. 6).

The mature epidermic exocarp (Fig. 13) maintained the same structure as in the young fruit stage. The differentiated mesocarp was parenchymatous and sclerenchymatous (Figs. 9 and 13). The sclerenchymatous mesocarp was made up of fibers that are arranged differently in 
the pericarp. There was a lignified fibrous middle layer (Fig. 13) whose large cellular axis was oriented longitudinally in the fruit. Two to three subepidermic fibrous layers, some lignified, crossed perpendicularly (Fig. 13). The endocarp was also fibrous and its cells were arranged in a way similar to the fibers of the inner mesocarp (Fig. 13).

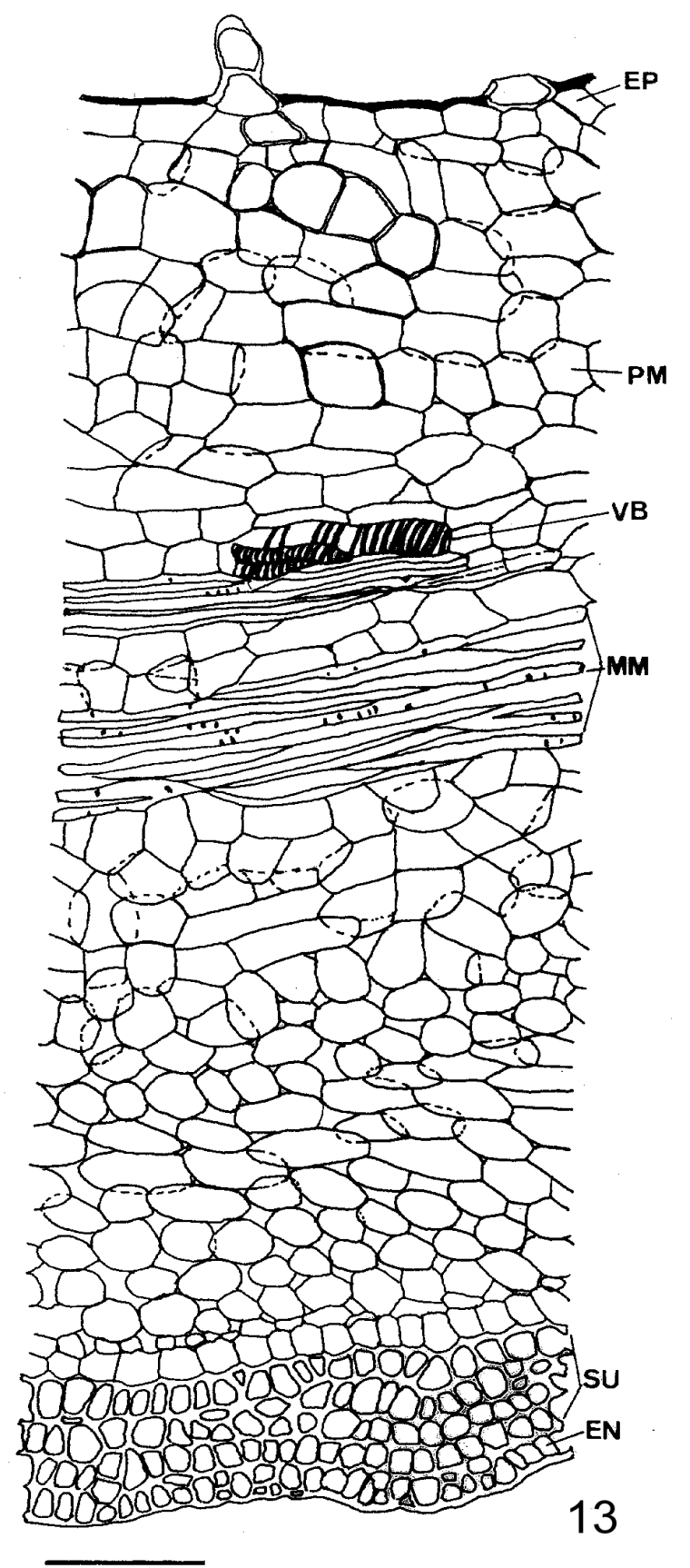

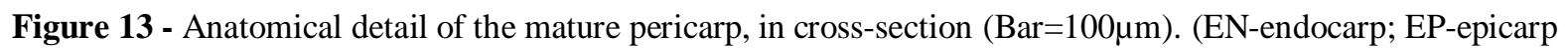


Vascularization of the mature fruit (Fig. 9) was made by dorsal bundles in the fruit dehiscence region, marginal bundles in the septum, seed traces and lateral or mesocarpic bundles. Lateral bundles were arranged in two rings in the mesocarp, the most external ring being composed of small bundles.

The dehiscence system of the fruit was complex. It was composed of separation tissue (Fig. 9) in the dorsal region, formed by small thin-walled spongy parenchyma cells (Fig. 14). This system was also constituted by two fibrous layers (middle and subepidermic) that cross in the pericarp (Fig. 13). The hygroscopic tension caused by the water loss of the fruit, associated with the structure of the fibrous pericarp, promoted the rupture of the separation tissue. In this way, the fruit dehisced through two longitudinal slits in the dorsal region (Fig. 4). Simultaneously, the rupture of the septum close to the wall of the fruit occurred, isolating a seminiferous column (Fig. 4). The fruit was classified as a loculicidal capsule.

MM-middle sclerenchymatous mesocarp; PMparenchymatous mesocarp; SU-subepidermic sclerenchymatous mesocarp; VB-vascular bundle)

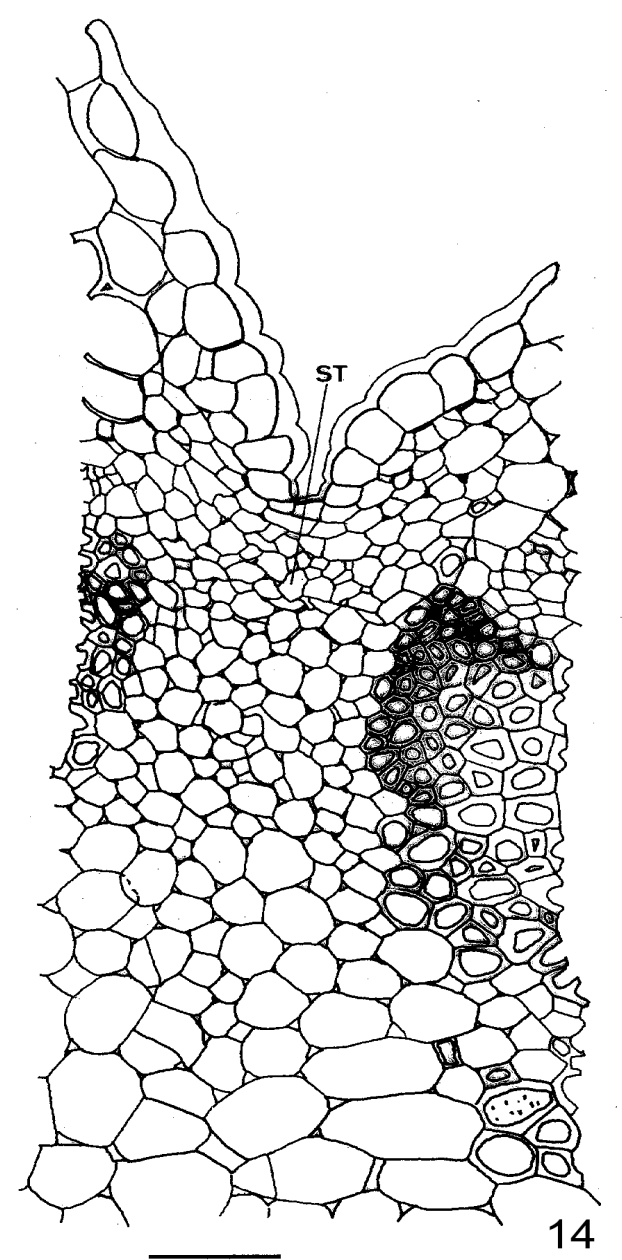

Figure 14 - Detail of the separation tissue, surrounded by fibers (Bar=50 $\mu \mathrm{m})$. (ST-separation tissue) 


\section{Seed}

The seed originated from an anatropous, unitegmic and tenuinucellate ovule (Fig. 15). The ovule had a very small funiculus and a well-developed hypostase (Fig. 15). Hypostase cell walls reacted positively to specific stain for lipid substances. The epidermic cells of the integument constituted the endothelium (Fig. 15), which stood out for its dense cellular content and short cylindrical form. At the micropyle level, the placentary cells were slightly elongated and did not have very thick walls (Fig. 15). Cellular content was stained more strongly.

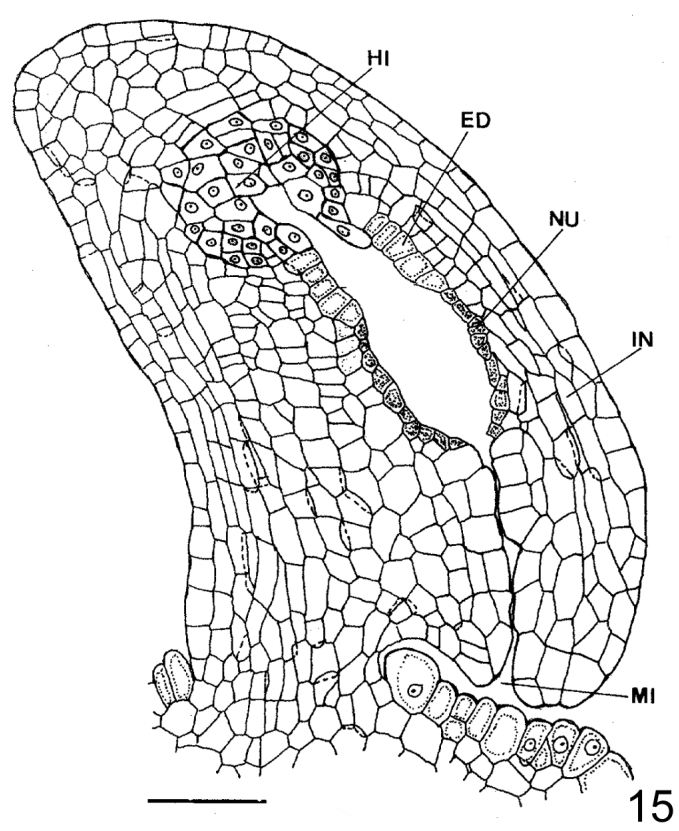

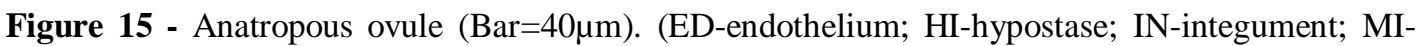
micropyle; NU-nucellus)

In the developing seed, the nucellus was absorbed. In the integument border, some epidermic cells were precursory to the wing (Fig. 21). These voluminous cells had dense cytoplasm and began a lengthening process (Fig. 22) followed by anticlinal cellular division. The endosperm was cellular (Fig. 18). The hypostase remained in the seed in differentiation (Figs. 16 and 17). Some hypostase cells divided toward the embryonic cavity (Fig. 19), becoming precursory cells of apomictic embryos (Fig. 17). In the young testa (Figs. 16 and 18), there was an increase in the number of cellular layers. The endothelium became biseriate (Fig. 18) or uniseriate. Mesotestal cellular layers next to the endothelium (Fig. 18) were destroyed, isolating the endothelium of the testa (Figs. 17 and 20). 


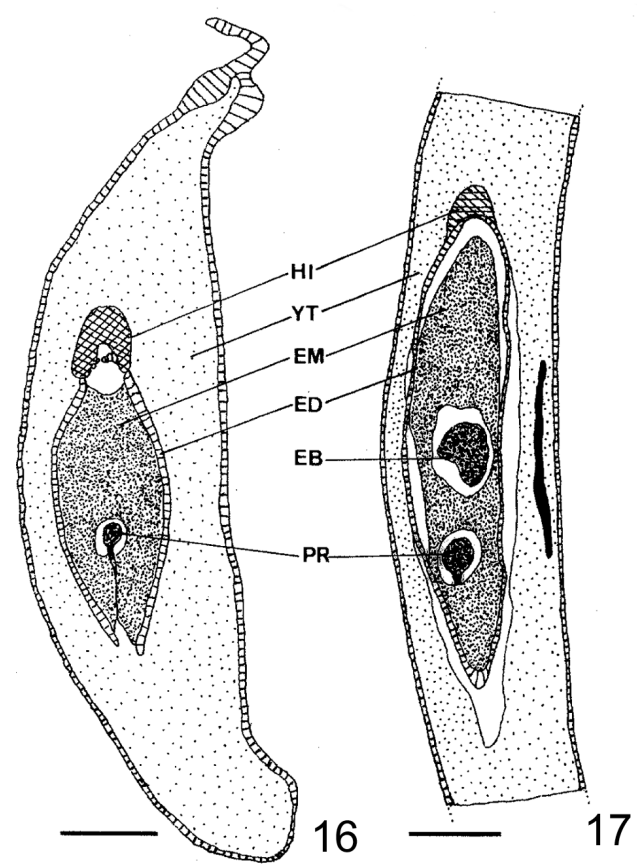

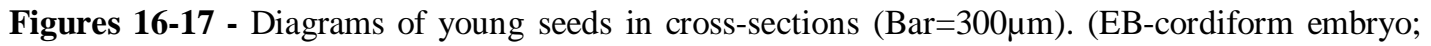
ED-endothelium; EM-endosperm; HI-hypostase; PR-proembryo; YT-young testa)
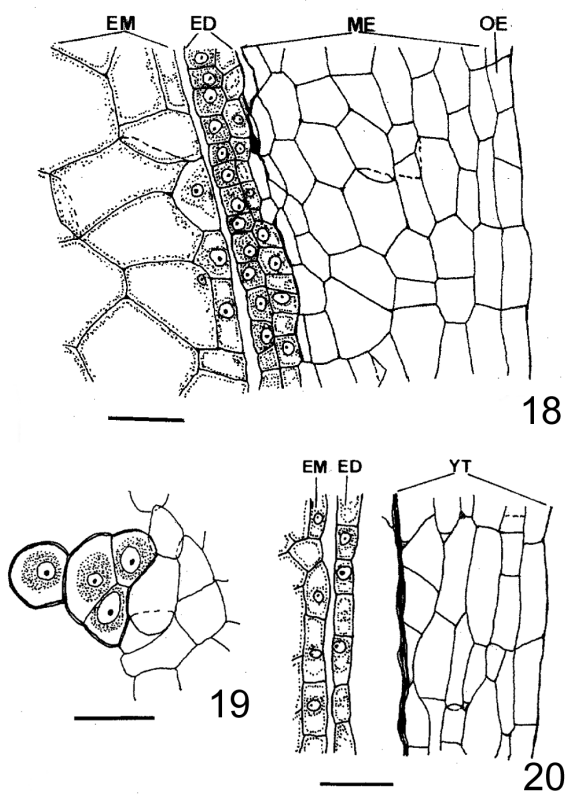

Figures 18-20 - 18 - Anatomical detail of the testa and endosperm observed in Figure $16(\mathrm{Bar}=30 \mu \mathrm{m})$; 19: Detail of cell proliferation of the hypostase $(\mathrm{Bar}=20 \mu \mathrm{m})$; 20: Anatomical detail of the young testa, endothelium and endosperm, shown in Figure 17 (Bar=30 $\mu \mathrm{m})$. (ED-endothelium; EM-endosperm; ME-mesophyll; OE-outer epidermis; YT-young testa) 


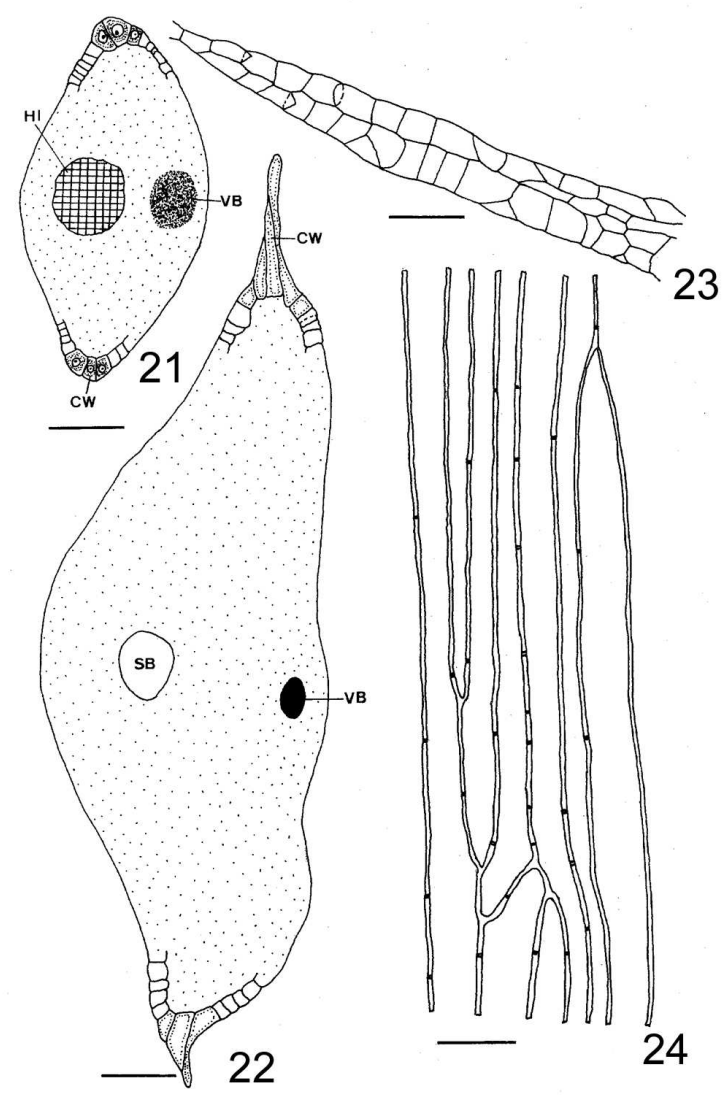

Figures 21-24 - Wing development of the seed. 21-22: Young seeds, showing precursory cells of the wing $(\mathrm{CW})(\mathrm{Bar}=50 \mu \mathrm{m})$; 23-24: Wing cells, observed in section and in front view (Bar=50 $\mu \mathrm{m})$. (HI-hypostase; SB-embryonic sac; VB-vascular bundle)

Mature seeds were alate (Figs. 26 and 27) and can present polyembryony (Fig. 29). The wing was membranous and it was possible to distinguish the embryonic contour in the interior of the seed body (Figs. 26 e 27). The raphe (Fig. 27) and hilum occurred in the testa. When it left, the endothelium and the endospermic layer completely covering the embryo remained (Fig. 25). Each seed possessed one to four embryos, the seeds with one or two being more frequent.

The seed was exotestal. The testa presented a fibrous epidermis and a compressed spongy parenchymatous mesophyll (Fig. 28). The fibers had lignified thick walls and simple pits (Fig. 28). The wing was made up of one or two fibrous layers of not very thick and non-lignified walls (Figs. 23 and 24). Endothelium cells were tabulate and vacuolized and arranged in a single layer (Fig. 28), occasionally two layers. Endospermic cells (Fig. 28) next to the endothelium were square, with dense cytoplasm and occurred in one or a few layers. Embryos were straight and possessed reniform cotyledons (Fig. 29) with lipid reserve. 


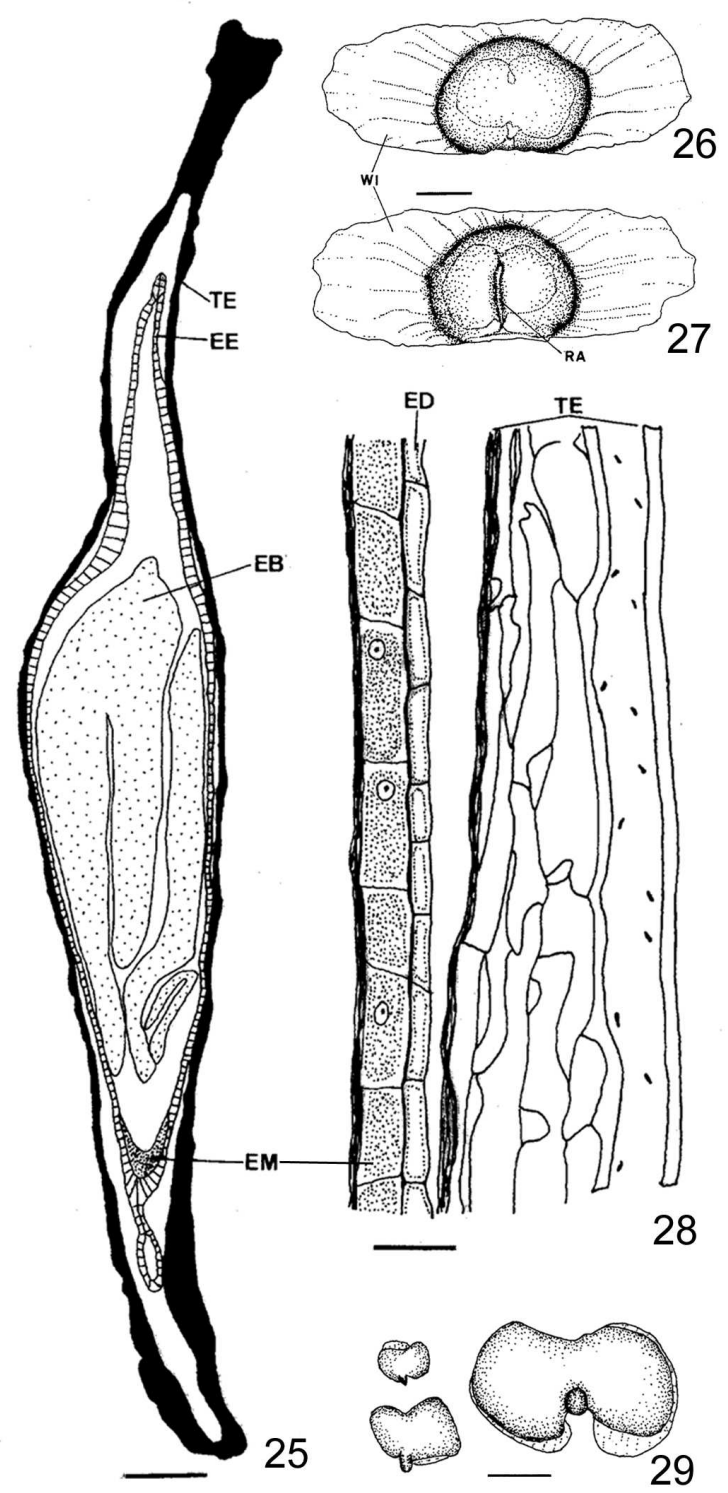

Figures 25-29 - 25 - Diagram of wingless seed, in longitudinal section (Bar=0.5cm); 26-27: Alate seeds $($ Bar $=0.5 \mathrm{~cm})$; 28: Anatomical detail of the testa, endothelium and endosperm $($ Bar $=20 \mu \mathrm{m})$; 29: Embryos of polyembryonic seed $($ Bar=0.5cm). (EB-embryo; EDendothelium; EE-endothelium and endosperm; EM-endosperm; RA-raphe; TE-testa; WI-wing)

\section{DISCUSSION}

The developing fruit of Tabebuia chrysotricha was anatomically very similar to the fruit of $T$. ochracea, a typical "ipê" of the Minas Gerais "cerrado" (Minas Gerais State, Brazil) (Costa, 2003). The ovaries of both species had the same structure, but presented different trichome development (T. chrysotricha - ovary stage; $T$. ochracea - very young fruit stage). Placentation of the two plants was similar. However, Costa (2003), based on a study of the floral vascularization of $T$. ochracea (Bittencourt Jr., 1995), considered the placentation of this species intermediate between axial and parietal. According to these authors, the two halves of the placentas were not fused, but occupied a marginal or submarginal position. In the case of the $T$. chrysotricha placentation, it was considered only 
axial because intermediate characterization only occurred in the developing fruit, in which the seeds approached the fruit wall in the accentuated growth of the septum.

With reference to the developing fruits of the two species, there were significant differences in the exocarp formation. In $T$. ochracea, there were ramified tector trichomes, with short branches and nectaries (Costa, 2003). In T. chrysotricha, on the other hand, the ramified trichomes were very different morphologically, and there were no nectaries.

As a dorsiventral structure, the carpel can develop a so-called ventral meristem on its inner surface, either in subepidermal layers or in the inner epidermis itself (or both strata). In very peculiar cases, a dorsal meristem can develop (Roth, 1977). The endocarp of many fruits of Leguminosae and Rutaceae species originates from the activity of a ventral meristem (Souza, 1984, 1993; Souza et al., 2003). On the other hand, the T. chrysotricha meristem did not occur on either carpel surface, only in the middle region, among the vascular bundles of the mesophyll.

T. chrysotricha fruits, similar to those of $T$. ochracea (Costa, 2003), were erroneously considered siliquas because they presented a seminiferous column and formed two valves at the time of dehiscence. However, according to Spjut (1994) and Barroso et al. (1999), the fruits of these species are actually loculicidal capsules, whose dehiscence occurred in the dorsal suture, with each valve formed by half of each one of the two carpels.

The anatomical background for dehiscence mechanisms is mainly based on the presence of two antagonistoc tissues (Roth, 1977). These tissues occurred in the pericarp of $T$. chrysotricha. They are formed by two fibrous layers (one in the middle region and the other in the ventral) and arranged so that the cells of one layer cross those of the other.

The presence of endothelium is recorded mainly in families that show unitegmic, tenuinucellate ovules, later developing ab initio cellular endosperm (Kapil and Tiwari, 1978). The authors include Bignoniaceae among these families. In fact, the ovule and the seed of $T$. chrysotricha, with these attributes possessed endothelium. Souza (1988), analyzing the seed of Lonchocarpus muehlbergianus Hassl., and Maheshwari (1971) suggest that the endothelium is a nutritive layer whose chief function is to serve as intermediary for the transport of food materials from the integument to the embryo sac. However, in the case of $T$. chrysotricha, this function can even be exercised in the beginning of seed development. But as the endothelium persists in the mature seed, it can also protect the embryo (Kapil and Tiwari, 1978).

The mature seed of $T$. chrysotricha followed the basic structural pattern of Bignoniaceae species (Corner, 1976). The seed, however, was not exalbuminous, although the existent endosperm, together with the endothelium, should protect the embryo more than feed it.

The seed of $T$. chrysotricha presented apomixis, based on studies of T. ochracea (Costa, 2003). In these species, a sexual embryo and several asexual embryos may arise from hypostase cells. Embryos that do not arise from cells of the gametophyte, but from those of the nucellus or the integument, are called adventive (Maheshwari, 1971).

\section{RESUMO}

Morfologia e estrutura de frutos e sementes em desenvolvimento de Tabebuia chrysotricha (Mart. ex DC.) Standl. (Bignoniaceae), espécie típica da floresta pluvial atlântica, são apresentadas e discutidas. Flores e frutos em diversas fases de maturação foram coletados no campus da Universidade Estadual de Maringá, Paraná, Brasil, e analisados em laboratório. $\mathrm{O}$ fruto é uma cápsula loculicida, que se abre por duas fendas dorsais, liberando coluna seminífera. $O$ processo de deiscência do fruto envolve principalmente tecido de abscisão e dois estratos mesocárpicos esclerenquimáticos cruzados, um médio e outro interno subepidérmico. A semente origina-se de óvulo anátropo, unitegumentado e tenuinucelado. A semente é exotestal e pode apresentar poliembrionia. Na semente madura conservam-se o endotélio e endosperma, que protegem o embrião. Os embriões adventícios formam-se de células da hipóstase.

\section{REFERENCES}

Barroso, G. M.ç Morim, M. P.ç Peixoto, A. L. and Ichaso, C. L. F. (1999), Frutos e Sementes: Morfologia Aplicada à Sistemática de Dicotiledôneas. Editora da Universidade Federal de Viçosa, Viçosa. 
Berlyn, G. P. and Miksche, J. P. (1976), Botanical Microtechnique and Cytochemistry. The Iowa State University Press, Ames, Iowa.

Bittenccourt Jr., N. S. (1995), Vascularização floral de Tabebuia ochracea (Cham.) Standley (Bignoniaceae). Rev. bras. Bot., 18 : (2), 143-155.

Corner, E. J. H. (1976), The Seeds of Dicotyledons. Cambridge : Cambridge University Press.

Costa, M. E. (1995), Morfoanatomia da semente e plântula de Tabebuia serratifolia(Vahl) Nicholson (Bignoniaceae). Dissertação de mestrado, Universidade Federal do Paraná, Curitiba, Brasil.

Costa, M. E. (2003), Morfoanatomia e desenvolvimento do fruto, semente e plântula de Tabebuia ochracea (Chamisso) Standley (Bignoniaceae). Tese de doutorado, Universidade Estadual Paulista, Rio Claro, Brasil.

Dnyansagar, V. R. (1958), Embryological studies in the Leguminosae VIII. Acacia auriculaeformis A Cunn., Adenanthera pavonina Linn., Calliandra grandiflora Benth. Lloydia, 21 :(1), 1-25.

Johansen, D. A. (1940), Plant Microtechnique. New York : McGraw-Hill.

Kapil, R. N. and Tiwari, S. C. (1978), The integumentary tapetum. Bot. Rev., 44 : (4), 457-490.

Lorenzi, H. (1992), Árvores Brasileiras - Manual de Identificação e Cultivo de Plantas Arbóreas do Brasil. Nova Odessa : Plantarum.

Maheshwari, P. (1971), An Introduction to the Embryology of Angiosperms. New Delhi : Tata McGraw-Hill Publishing Company.

Roth, I. (1977), Fruits of angiosperms. In: Linsbauer, K.; Tischler, F. G. and Pascher, A. (Eds.). Encyclopedia of Plant Anatomy. Berlin : Gebrüder Borntraeger. 666 pp.

Souza, L. A. (1984), Anatomia do desenvolvimento do pericarpo de Lonchocarpus muehlbergianus Hassler (Leguminosae - Faboideae). Rev. Unimar, 6, 5-19.

Souza, L. A. (1988), Anatomia de estádios de desenvolvimento da semente de Lonchocarpus muehlbergianus Hassl. (Leguminosae - Faboideae). Garc. Orta, Sér. Bot., 10 : (1-2), 1-9.

Souza, L. A. (1993), Morfo-anatomia do desenvolvimento do fruto de Acacia paniculata Willd. (Leguminosae). Arq. Biol. Tecnol., 36 : (4), 851-871.

Souza, L. A., Mourão, K. S. M., Moscheta, I. S. and Rosa, S. M. (2003), Morfologia e anatomia da flor de Pilocarpus pennatifolius Lem. (Rutaceae). Rev. bras. Bot., 26 : (2), 175-184.

Spjut, R. W. (1994), A systematic treatment of fruit types. Mem. New York Bot. Gard., 70, 1-182. 